\title{
O ENSINO DE GRAMÁTICA NA REVISTA ESCOLA SECUNDÁRIA (1957-1963)'
}

Luci Schmoeller Norberto Dallabrida ${ }^{(*)}$

INTRODUÇÃO

\begin{abstract}
"[...] o peso asfixiante da rotina continua a abafar o ensino do idioma. Como essas trepadeiras envolventes e daninhas, continuam as antigas regras, puramente artificiais, ou já sem aplicação aos nossos dias, a enredar-se em torno do velho roble português, impedindo-o de frondejar à larga, à desenvolta [...] o aprendizado do português tem por finalidade colocar nos lábios dos estudantes expressões e conhecimentos que lhes sirvam de apto e perfeito instrumento de intercâmbio social de ideias e sensações".
\end{abstract} Francisco da Silveira Bueno

As transformações pelas quais passou a disciplina de português no Brasil no ensino secundário não modificaram a primazia dada à análise gramatical - especialmente morfológica e sintática -, cuja origem tem influência do tratamento metalinguístico dado ao ensino do latim e do grego. O "peso asfixiante da rotina" - nas palavras de Bueno - é o que nos leva a pensar que aula de português é aula de gramática; mais precisamente como o estudo de regras mais ou menos explícitas de construção de estruturas - regras ortográficas, de concordância e de regência, de colocação pronominal etc. - ou a análise de determinadas construções e categorias - classes de palavras e análise sintática, por exemplo. Segundo Possenti (2000), essas duas atividades estão muito frequentemente relacionadas, isto é, para ensinar as regras da norma culta, usa-se o auxílio da metalinguagem. Conforme o autor, os termos metalinguísticos deveriam ser suprimidos, em vez disso, propor substituições de formas não cultas por outras adequadas socialmente. Há muito, professores e teóricos tentam romper com essa tradição de ensino da metalinguagem, no entanto, essa característica se enraizou na pedagogia do vernáculo de tal maneira que metodologias alternativas não têm aceitação nem por professores, nem por alunos, nem por pais. Da mesma forma, o ensino da leitura como pretexto para a análise metalinguística, a imposição da leitura dos

\footnotetext{
${ }^{1}$ Este artigo é resultado de parte da pesquisa para a tese de doutoramento em História da Educação pelo PPGE da UDESC.

${ }^{(*)}$ Doutoranda do programa de Pós-graduação em História da Educação na UDESC, mestre em linguística pela UFSC e professora de Língua Portuguesa do ensino básico na Escola de Aprendizes-marinheiros de Santa Catarina. E-mail: lucischmoeller@hotmail.com

Doutor em História Social pela USP e professor do Programa de Pós-Graduação em Educação da Universidade do Estado de Santa Catarina (UDESC). E-mail: norbertodallabrida@ hotmail.com.

${ }^{2}$ Citação presente na Revista Escola Secundária, n. 3, , p. 39 dez. 1957, do autor Francisco da Silveira Bueno.
} 
cânones e a valorização demasiada da variedade linguística da elite ainda têm vez nos planos das aulas de português de hoje.

As décadas de 1950 e 1960 foi um período em que houve modificações significativas no ensino do vernáculo - assim como em outras disciplinas - devido à democratização do acesso à escolarização. Por um lado, nessa época, as exigências da produção demandavam operários que, no mínimo, soubessem ler; de outra parte, as camadas populares lutavam pela democratização do saber através da democratização da escola (SOARES, 1986). Chegaram aos bancos das escolas públicas alunos provenientes das camadas sociais menos favorecidas, e estes alunos falavam diferente, além de terem construção de categorias outras através das quais interpretam o mundo. A escola, que não estava adequada a essa nova realidade, não aceitava, ou sequer compreendia, os falares e os saberes desses alunos. A língua era vista como estática, pronta; a imagem de uma língua correta e adequada é responsável pelas qualificações e estigmatizações postas em prática pelos falantes (GERALDI, 2009). A que se acrescentar a esses fatores de mudança, a figura do professor - antes um estudioso da língua, proveniente das camadas mais elitizadas e bem remunerado -, com a demanda para suprir o número de escolas públicas que se multiplicou rapidamente, teve de ser recrutado num processo menos seletivo; os manuais didáticos assumiram a responsabilidade, antes do professor, de formular exercícios de vocabulário, de interpretação, de redação, de gramática. Tudo isso, segundo Soares (2004), resultou no processo de depreciação da função docente, que conduziu ao rebaixamento salarial e à precariedade das condições de trabalho.

A arraigada tradição de ensino dos chamados conteúdos gramaticais começa, nesse período, a ser questionada. Geraldi (2009, p. 122) reproduz algumas das observações de Rui Barbosa (1946) sobre o ensino do vernáculo:

$\mathrm{Na}$ escola atual, o ensino começa pela síntese, pelas definições, pelas generalizações, pelas regras abstratas. [...] O fruto desse processo irracional é digno do método, que sistematiza assim a mecanização da palavra, descendo-a da sua natural dignidade, para a converter numa idolatria automática do fraseado. [...] é de definições, de classificações, de preceitos dogmáticos que se entretece todo este ensino.

Geraldi ratifica as observações de Rui Barbosa e afirmando que essa tradição, pautada nos estudos gramaticais, supõe que a partir desse conhecimento cada um de nós melhoraria seu desempenho linguístico. Segundo ele, a escola agiria como se para aprender a usar um interruptor ou uma tomada elétrica fosse necessário saber como a força da água se transforma em energia e esta em claridade na lâmpada que é acesa. Através dessa simples metáfora, Geraldi reafirma a posição 
de que o conhecimento gramatical não é, em seu todo, um conhecimento necessário para aquele que quer aprender a ler criticamente e a escrever exitosamente.

Essa discussão se colocava em artigos de autores da revista Escola Secundária, periódico educacional trimensal criado, em 1957, pela Campanha de aperfeiçoamento e difusão do Ensino Secundário (CADES) com o intuito de auxiliar os professores na elaboração da sua metodologia de ensino inovadoras. A CADES integrava a Diretoria do Ensino Secundário (DES) do Ministério da Educação e Cultura, que era dirigida por Gildásio Amado. Os dezoito números publicados versam sobre diversas áreas; os artigos acerca das diferentes áreas do saber eram noticiários de cursos e encontros, da aplicabilidade de técnicas e métodos de ensino, do planejamento do conteúdo, de materiais didáticos, da avaliação da aprendizagem. Neste trabalho analisamos os artigos que tratam do ensino de gramática, que foram escritos por professores de língua vernácula que refletiram sobre ou ousaram fazer experimentos nas suas aulas, de sorte que é notório que a revista teve um quê de modelar, de fazer criar uma nova roupagem para as disciplinas, esse fato é importante para pensarmos o contexto de produção dessas edições. O recorte da pesquisa, em foco neste artigo, foi justamente sobre a questão mais polêmica nas discussões acerca do ensino de português - o ensino da gramática.

Para tanto, consideramos que a finalidade do ensino de uma determinada disciplina-saber passa por momentos de transformação significativa. Segundo Chervel (1990, p. 198), “a disciplina, ainda que pareça imune por todos os lados, não é uma massa amorfa e inerte. Vê-se de repente florescerem os 'novos' métodos que dão testemunho de uma insatisfação e dos quais o sucesso é também o questionamento ao menos parcial da tradição". A taxa de renovação do corpo docente é um fator determinante para a renovação das disciplinas-saber, bem a realização de conferências e de congressos e a publicação de manuais escolares, periódicos pedagógicos, entre outros impressos (CHERVEL, 1990). E esse papel ativo e criativo que a escola desempenha só é possível evidenciar a partir da pesquisa da história das disciplinas-saber. É a partir desses pressupostos que são analisadas as materialidades relacionadas ao ensino da língua vernácula no Brasil presentes nas edições da revista Escola Secundária. 


\section{O QUE DIZIAM OS PROFESSORES SOBRE OS OBJETIVOS DO ENSINO DA LÍNGUA PORTUGUESA}

O primeiro artigo sobre o ensino de português, $\mathrm{n}^{\circ} 01$ de 1957, versa sobre os objetivos do ensino da língua vernácula. A professora Adolphina Portela Bonapace ${ }^{3}$, que assina o artigo, já apontava outros caminhos:

o professor não ensinará aos alunos a gramática da língua vernácula como se tivesse mérito próprio, como se a gramática pudesse ser considerada um fim em si mesma. Muito pelo contrário, procurará subordinar a aprendizagem gramatical ao objetivo máximo do estudo da língua pátria. De que servirá ao aluno memorizar extenso, complexo e erudito compêndio de gramática, se não souber relacionar as normas teóricas às suas dificuldades e dúvidas no escrever e no falar? (BONAPACE, 1957, p. 29)

O objetivo máximo ao qual se refere a autora é "a expressão correta e elegante do pensamento, em língua vernácula, oralmente ou por escrito" (BONAPACE, 1957, p. 29). No entanto, tal é a força da tradição, que a autora se contrapõe à sua ideia vanguardista de uma abordagem mais funcional da língua. No parágrafo seguinte, reforça que "os exercícios de análise léxica e sintática concorrerão para o aperfeiçoamento do aluno na expressão oral e escrita de suas ideias" (BONAPACE, 1957, p. 29), reforçando que, ao estudar a análise sintática, o aluno vai compreender de maneira mais profunda a estrutura dos textos, através dos períodos e orações, e assim saberá imitá-los nas suas redações:

Tendo dissecado, pela análise sintática, os textos, poderá compreendê-los e senti-los mais facilmente no mecanismo básico de sua constituição e elaboração, e aplicar os conhecimentos adquiridos aos trabalhos pessoais de redação. (BONAPACE, 1957, p. 29).

Já o professor Alvacyr Pedrinha ${ }^{4}$ (1957) exemplifica sua posição contra o ensino pautado na análise sintática com o fato de que existem alunos desconhecedores dos meandros da língua e que escrevem com correção e elegância, enquanto outros apresentam redações deficitárias, apesar de dominar toda a sua engrenagem. Assim, vemos o quão difícil é a tarefa de se despir de séculos de tradição e ousar pensar um ensino de língua vernácula diferente. Todavia, não devemos nos furtar de reconhecer que a discussão sobre o assunto fomentou novos caminhos para pensarmos a metodologia e os objetivos da disciplina nos dias de hoje.

\footnotetext{
${ }^{3}$ Pouco se sabe sobre a carreira da Professora Bonapace, senão que exerceu o magistério e escreveu: Considerações sobre a educação nacional, publicado na revista Curriculum, out./dez. 1972 e sua tese de mestrado: O Romanceiro da Inconfidência: Meditação sobre o destino do homem, para a Faculdade de Letras da UFRJ, 1974.

${ }^{4}$ Alvacyr Pedrinha (1919-1998), bacharel em Letras clássicas pela faculdade Nacional de Filosofia, lecionou no Pedro II, foi membro da academia brasileira de Filologia (VALLE, Rosalvo. Discurso de homenagem póstuma ao acadêmico Alvacyr Pedrinha, 13 de março de 1999. Disponível em: 〈http://www.filologia.org.br/abf/rabf/1/156. pdf >. Acesso em: 04/11/2015).
} 
Nas abordagens presentes na revista Escola Secundária, é possível encontrar, por exemplo, a defesa de uma educação integral. Bonapace (1957, p. 29) defende que o objetivo do ensino secundário deve ser a formação do educando: "na mais ampla acepção da palavra: formação religiosa, moral, cívica, artística e cultural” a acrescenta que, uma vez que o ensino primário já forneceu os instrumentos básicos de trabalho, o secundário completaria o preparo básico e oportunizaria o ingresso no curso superior. A analogia da construção civil é utilizada por ela para dizer que a construção de um edifício da formação cultural - integral - do educando requer determinado número de tijolos, sendo que a aprendizagem da língua vernácula está desde o alicerce até o esplendor da cúpula. É notório que aqui estão sendo apropriadas ideias de educação integral defendidas pela Escola Nova.

Da mesma forma, Ismael de Lima Coutinho ${ }^{5}$ aborda concepções vanguardistas baseadas nos pensamentos de John Dewey - um dos mais célebres escolanovistas. Coutinho (1959) defende que a linguagem, sendo instrumento de comunicação, estabelece e expande o espírito de sociabilidade, além de ser o veículo pelo qual o indivíduo adquire necessária noção das coisas e dos conhecimentos científicos; sem ela não seria possível o progresso. A partir dessa concepção de linguagem, apresenta os objetivos para o ensino do vernáculo: habilitar o educando a falar e a escrever corretamente o idioma, despertar-lhe o gosto literário e o amor pela língua pátria, contribuir para a sua formação moral e intelectual e cooperar para a criação de uma consciência patriótica e humanística. Analisando a historicidade do texto, podemos notar a forte influência do sentimento nacionalista, de exaltação das coisas pátrias para a criação de uma nação pela linguagem, influenciando deveras a constituição da disciplina do ensino da língua vernácula. Vemos, ainda, o diálogo com Bonapace, no que diz respeito à formação integral do educando, aliando moral, civismo e cultura.

O professor Antonio Fernandes Deléo ${ }^{6}$ disserta, no seu artigo "O ensino de português", do número 15 de 1960, sobre como devem ser as aulas de português para que se consiga educar para a vida. O autor, através de divertidas narrativas de experiências na sala de aula, faz a defesa de algumas metodologias inovadoras: trabalhos em grupo para praticar a oralidade; torneios entre as

\footnotetext{
${ }^{5}$ Coutinho nasceu no Rio de Janeiro. Lecionou, inicialmente, no Colégio Silvio Leite, no Rio de Janeiro. Concluiu, em dezembro de 1932, o curso de ciências jurídicas e sociais pela Faculdade Nacional de Direito, lecionou português, latim e grego nos colégios Bittencourt Silva e Brasil, Chegou a coordenador dos cursos do Instituto de Educação da Guanabara. Em 1938 publica sua principal obra, a Gramática Histórica. Foi membro fundador da Academia Brasileira de Filologia e ocupou, na Academia Fluminense de Letras. (ROBERT, Maria Teresa C. Ismael de Lima Coutinho e os estudos linguísticos no Brasil. Revista Philologus, ano 17, n. 50. Rio de Janeiro: CiFEFiL, maio/ago. 2011).

${ }^{6}$ Sobre o professor Deléo poucas informações constam na internet, somente que nos últimos anos tem proferido palestras motivacionais que abordam o tema Educação Operante e Transformadora.
} 
turmas de diferentes séries, promovendo situações de interação reais em que os alunos têm de treinar as competências linguísticas; escrita e apresentação de óperas; no ensino do vocabulário, a experiência de vida dos alunos deve ser o ponto de partida para fazer associação com elementos que o aluno já possui; o aprendizado do sentido das palavras é facilitado se o aluno mesmo indicá-las; o estímulo à curiosidade e à prática da oralidade, o professor deve ouvir sempre o aluno; o bom exemplo do uso de linguagem clara, acessível - quebrando o tabu de que falar com clareza e correção é falar "difícil"-; a exortação de que é preciso fazer força para aprender, que "esse esforço é um prêmio em si e produz resultados ótimos" (DELÉO, 1960, p. 58); o uso do quadro negro deve ser eficiente, isto é, é preciso fazer os alunos usarem o quadro negro; as aulas em campo aberto para observação de paisagens e treino de adjetivações. Enfim, o professor Deléo incita o ensino ativo, através de experimentações, e conclui (DELÉO, 1960, p. 59): "E mais do que tudo, meu caro, mais do que tudo, mostre que em suas aulas se aprende para a vida. Em cada atitude sua, prove isso".

Além desses vanguardismos, podemos apontar ainda uma ideia que hoje é alvo de intensa discussão pelos curriculistas: a interdisciplinaridade. Bonapace (1957, p. 30) defende que "as diversas matérias que constituem o currículo secundário não podem ser consideradas compartimentos estanques, todas estão intimamente relacionadas, fundem-se e completam-se para a formação geral do educando" e explica que os conhecimentos adquiridos em língua portuguesa são aplicados em todo o curso secundário: nas reconstituições históricas, nas explicações geométricas e científicas, nas traduções; enfim, o aluno que domina bem a língua vernácula poderá ter êxito nas outras áreas também. Dessa forma, a professora chama a atenção para a necessidade de os professores das outras matérias auxiliarem no trabalho do professor de português atentando para a produção de textos e exigindo dos alunos comprometimento com o idioma oficial. No mesmo viés, Coutinho (1959) afirma que as aulas de literatura e de história podem fazer conexões e dar subsídios para uma visão mais ampla da história e da língua que falamos. Além dele, o professor Freixieiro $^{7}$ (1958) defende veementemente o entrosamento efetivo com as disciplinas de latim, geografia e história, permitindo ao educando uma visão geral da formação da língua portuguesa, localizando a língua no tempo e no espaço, refletindo sobre as fronteiras políticas e linguísticas, em benefício da cultura geral do educando. Ainda em outro artigo, o professor Freixieiro (1960), ao

\footnotetext{
${ }^{7}$ Fabio Mello Freixieiro, um dos que mais contribuiu com artigos para a Revista Escola Secundária, era crítico literário e professor. Foi signatário de um documento, endereçado a Anísio Teixeira e encabeçado por Lourenço Filho, com outros 528 educadores, em 1958. O documento explicita a solidariedade a Anísio e às ideias defendidas por ele acerca da educação brasileira (LOURENÇO FILHO, M. B. e outros. Manifesto de 529 educadores. Educação e Ciências Sociais. Rio de Janeiro, v. 3, p.143-145, n. 8, 1958.).
} 
apresentar o curso e o programa experimentais de português, volta a defender a necessária articulação entre as matérias português, latim, geografia e história.

\section{GRAMÁTICA NORMATIVA E DESCRITIVA: SUGESTÕES DOS PROFESSORES SOBRE MÉTODOS DE ENSINO E A QUESTÃO DA ANÁLISE SINTÁTICA}

“Ensinar apenas gramática e análise sintática é mesmo muito mais fácil do que ser Professor de Português...”

José Aluísio Aragão

O trecho do professor Aragão, retirado do artigo publicado pela Escola Secundária (n. 17, jun. 1961), inscreve bem o quão instigantes eram as ideias acerca do ensino de gramática publicadas naquela revista. A definição mais adotada nas gramáticas pedagógicas e nos livros didáticos e a mais conhecida dos professores é a definição de gramática como um conjunto de regras a serem seguidas (POSSENTI, 2000), já que o mister do professor é fazer com que o aluno fale e escreva corretamente. Gramáticas desse tipo são conhecidas como normativas ou prescritivas (POSSENTI, 2000. p. 65). Cabem nessa definição os ensinos de concordância, de regência, de crase, de conjugação verbal etc. Segundo Britto (1997), o estabelecimento de regras prescritivas da gramática não é mais do que um mecanismo de desvalorização e de exclusão das variantes sem prestígio em nome de uma única modalidade, a culta. É evidente, segundo Britto (1997, p. 34), que

“os gramáticos expressam os valores de uma comunidade de falantes cuja variedade linguística, por razões históricas, impôs-se como mais correta e superior às demais, em grande medida, por ter servido de base para a constituição da modalidade escrita”.

Esse preconceito linguístico é social e ideológico que, segundo Britto (1997) não decorre da compreensão objetiva da realidade. Segundo o autor, a partir da reflexão sobre o trabalho de Paulo Freire, a imposição de uma variante determinada não se confunde com educação linguística, esta última se justifica na medida em que é uma forma de acesso ao domínio da escrita - instrumento fundamental de intervenção do sujeito na sociedade letrada. Não é raro encontrar essa fusão no cotidiano escolar, menos raro ainda é encontrar práticas de ensino da prescrição da modalidade culta a partir do ensino da metalinguagem, isto é, a partir da análise da descrição dos fatos da língua.

A segunda definição de gramática que Possenti (2000, p. 65) aborda é a gramática como um conjunto de regras que são seguidas, é a gramática descritiva. A preocupação central quando se tem como foco a gramática descritiva é descrever e explicar os fatos de uma língua. Apesar das distinções, as passagens descritivas de uma gramática normativa referem-se às formas corretas, por isso descrição e prescrição muitas vezes se fundem no ensino da língua. A distribuição das palavras 
em classes gramaticais, a distinção das partes da oração, a segmentação das palavras em radical, vogal temática e desinência fazem parte da descrição dos fatos linguísticos - Apesar de a classificação lexical e a nomenclatura serem também importantes nas discussões do ensino do vernáculo, é a análise sintática que mais mobiliza as intervenções dos autores da revista. Assim, é compreensível que quando se fala em aulas de português se tenha em mente tanto a descrição lexical e sintática, quanto a normatização da modalidade culta da língua.

A espinha dorsal do ensino de língua materna, conforme aponta o Prof. Alvacyr Pedrinha, foi sempre o ensino da metalinguagem, mais precisamente a unidade sobre análise sintática, que se estende em todas as séries do secundário. Pedrinha (1957) exorta os professores que dedicam grande parte do ano letivo a dissecar períodos e mais períodos e reforça que, analisar sintaticamente um período, concorre para desenvolver no educando especificamente o raciocínio, a habilidade de pontuar com segurança e, sobretudo, de inteirar-se do texto, sendo essas três ações o alvo a que se visa na disciplina de português. Bonapace (1957, p. 29) ratifica essa posição e chama a atenção dos professores - leitores da revista - para as práticas de exercícios de análise léxica e sintática que devem concorrer para o aperfeiçoamento do aluno na expressão oral e escrita de suas ideias e acrescenta: "Um professor sensato sabe perfeitamente quão absurdo seria fazer da chamada 'análise lógica ${ }^{, 8}$ a essência do ensino e da aprendizagem do vernáculo".

Como sugestões de metodologias diferenciadas, Pedrinha apresenta em seu artigo (1957, p. 52) abordagens motivacionais, ou dicas para fomentar a curiosidade do aluno acerca da estrutura da língua e para que ele entenda a finalidade de se estudar essa estrutura. Chamando de "boa técnica", Pedrinha sugere apresentar um trecho bastante conhecido do aluno, como, por exemplo, o primeiro trecho do Hino Nacional em que, geralmente, não se sabe a qual sujeito se refere o verbo “ouviram”. Ao explicar à turma o sentido da proposição, induzindo-o a reconhecer o sujeito, "o aluno sentirá por experiência própria que houve apreensão do significado do período analisado e quão é importante o aprendizado que vai fazer”. Além dessa, Pedrinha (1957) acrescenta a dica de recorrer a outras motivações como, por exemplo, uma frase não bem pontuada que provoque ambiguidade. Indica, ainda, o estudo de períodos coordenativos e subordinativos, alertando para que se evite a memorização mecância, isto é, orientar o aluno para apreender o sentido da frase: "Procedendo assim, o professor exige dos alunos raciocínio, propriedade e precisão de linguagem para classificar conjunções, atitude esta que transferirão para outros problemas que terão de

\footnotetext{
${ }^{8}$ A análise lógica era feita através da análise de estruturas linguísticas de textos antológicos que "levada ao exagero e a um vazio de só servir a si mesma, passou a ser, entre muitos professores, o centro de preocupação de suas aulas" (BECHARA apud CLARE, p. 10).
} 
enfrentar durante o ginásio" (PEDRINHA, 1957, p. 52). Indica também que a memorização do aprendizado seja feito através estudo dirigido para dar mais autoconfiança e para eliminar as dificuldades encontradas pelo aluno. No ensino das orações reduzidas, segundo Pedrinha (1957, p. 52), o professor não deve desdobrá-las "em hipótese alguma", visto que o aluno não estaria analisando o que está escrito e poderia desfigurar o pensamento original. Também, segundo ele, não é justo propor análises de trechos que contenham idiomatismos, pois não suportam uma análise sintática, ou tendo sido feita, ela nada esclarecerá. Podemos inferir, então, que, no pensamento de Pedrinha, a análise sintática deve ser feita a partir de frases prontas e ideais para o propósito a que se quer chegar.

Apesar de, no seu discurso, Pedrinha (1957, p. 51) questionar os professores que dedicam grande parte do ano letivo a dissecar ${ }^{9}$ períodos e mais períodos, na página seguinte afirma que, na segunda série, o aluno já estará apto a fazer a anatomia do período sozinho (PEDRINHA, 1957). A mesma metáfora médica, utilizada para reforçar o discurso contrário, é forjada para enfatizar o ensino da língua através do aprendizado da estrutura sintática de períodos. Ao dissecar, o aluno estaria separando as partes da oração e analisando sua estrutura, isto é, a anatomia das construções linguísticas, o que, segundo o próprio Pedrinha (1957), não garante a prática de redações com correção e elegância.

Bechara $^{10}(1959$, p. 46) atribui a tradição de um ensino gramatical descritivo à adoção, nas escolas, de gramáticas de autores cujos estudos linguísticos se ancoravam no critério filológico e na ênfase na descrição da língua. Quanto a isso, Bechara (1959), através do empréstimo da voz do professor Said Ali - 1898 - ainda acrescenta que o despreparo pedagógico dos professores de português da época, embora muito conhecedores da matéria que ensinam. Esse fato estaria na raiz do fracasso do método de ensino da língua vernácula, uma vez que os professores eram estudiosos da língua e não tinham o necessário preparo pedagógico para saber o que deve ensinar às crianças e o que deve ser reservado para cérebros mais desenvolvidos capazes de compreender o valor de certas generalizações e abstrações. Quando critica o que hoje poderíamos chamar de transposição didática, conceito de Chevallard (1991 apud MATOS FILHO, 2008) - o professor Ali antecipa a

\footnotetext{
${ }^{9} \mathrm{O}$ autor utiliza a mesma escolha lexical de Bonapace no artigo da primeira edição da Revista Escola Secundária.

${ }^{10} \mathrm{O}$ professor Bechara é conhecido por seu trabalho, suas publicações e defesa que faz da fusão da ortografia nos países luso-brasileiros. Cursou Letras, modalidade neolatinas, foi professor do Colégio Pedro II, aperfeiçoou-se em Filologia Romância em Madri, doutorou-se em Letras pela atual UERJ, em 1964. Foi membro titular da Academia Brasileira de Filologia. Ocupou cargos políticos voltados à educação no estado do Rio de Janeiro e em inúmeras academias de letras, além da Academia Brasileira de Letras. É autor de diversos títulos, dentre eles a Moderna Gramática Portuguesa, amplamente utilizada em escolas e em meios acadêmicos. Disp.: 〈http://www.academia.org. br/〉. Acesso em $04 / 11 / 2014$.
} 
crítica de Chervel (1990) à roupagem didática que é dada para a escolarização de saberes científicos. Bechara (1959, p. 47) acrescenta que "a gramática científica expõe o fato linguístico; a normativa aconselha-o ou repudia-o". Segundo ele, é essa gramática normativa, prática, que deve fazer parte do currículo escolar e não a exposição metódica dos fatos da linguagem.

Nesse viés, Bechara (1959) afirma que, para os propósitos do ensino médio, a missão do professor é assentar a disciplina ${ }^{11}$ gramatical ou fazer com que os alunos busquem a correção da linguagem - hoje chamaríamos de ensino da norma de prestígio. E acrescenta a voz de Mattoso Câmara Junior para conceituar correção gramatical como a linguagem elegante de uma elite social, como a corte ou a burguesia abastada de uma cidade capital; ou a linguagem usada pelos grandes escritores, não esquecendo que a língua se modifica e que a gramática normativa ensinada nas escolas deve acompanhar essas mudanças. Segundo Bechara, nesses conceitos é que o professor deve ancorar-se para levar à escola a um processo de realizações construtivas no ensino da língua vernácula.

O autor acrescenta que merece repúdio dos mestres e providências enérgicas das autoridades competentes dois males que pululam em malefício do processo de ensino-aprendizagem da língua vernácula: os conhecimentos exigidos em concursos públicos e os livros feitos sem o devido preparo dos autores. No primeiro caso, Bechara (1959) chama a atenção para as provas de concursos públicos que não acompanham a evolução da gramática normativa, criando um fato desconcertante: uma gramática para a escola e outra para os concursos. No segundo caso, o autor denuncia os livros que deturpam a evolução da gramática normativa e se atêm aos purismos já ultrapassados. No entanto, cita o professor Sousa da Silveira para ressalvar que é preciso manter no horizonte a correção da linguagem: "Fale-se e escreva-se sem afetação. Haja naturalidade no falar e naturalidade no escrever. Mas tenha-se na lembrança que a naturalidade do falar nem sempre se admite no escrever, transportada ao falar, pode converter-se em afetação ou pedantismo" (BECHARA, 1959, p. 49).

Sem fazer referência ao nome do autor, Bechara inicia sua explanação acerca do programa de gramática para o ensino médio com as palavras de um filósofo alemão: “aprende-se a gramática pela língua e não a língua pela gramática” (BECHARA, 1959, p. 49). Essa citação já nos dá em boa medida a indicação de que Bechara também comunga das críticas ao ensino de gramática pela gramática. Bechara acrescenta que é tarefa improfícua e errônea essa orientação, devendo o

\footnotetext{
${ }^{11}$ Aqui o vocábulo "disciplina”, utilizado pelo autor, parece-nos indicar a vigília e o cuidado com o uso da língua, num sentido muito mais próximo do termo "disciplina-corpo".
} 
professor partir da realidade linguística dos textos e da própria expressão dos alunos para inculcar as noções do uso adequado da língua. $\mathrm{O}$ autor também se mostra contrário às listas enfadonhas de memorização e defende que o estudo da análise sintática é utilíssimo, desde que feito com sobriedade e desde que leve à análise das relações de sentido e de dependência e independência que as palavras, orações e expressões mantêm entre si e ainda instiga: "não é possível analisar um trecho, se não lhe compreende o sentido, e se ele se compreende, para que serve analisá-lo?" (BECHARA, 1959, P. 50).

Como sugestão metodológica para a execução do ensino do português, Coutinho (1959) traz uma novidade: o uso do texto para alcançar o estudo das regras gramaticais. Coutinho observa que, tendo em vista o traço gramatical e ser estudado, o professor deve selecionar o texto; um mesmo texto pode servir a vários propósitos, mas a insistência num único texto pode prejudicar o estudo por não despertar mais o interesse do aluno, uma vez que já é conhecido o texto. Do mesmo modo, Coutinho sugere o uso não só de textos em prosa, como também em verso; as poesias, por exemplo, são excelentes para o estudo da linguagem figurada. A lição de gramática, contudo, deve sempre vir em último lugar; essa ressalva é enfatizada no artigo de Coutinho, visto que a leitura, a interpretação, o estudo do vocabulário e da ortografia devem preceder a análise gramatical. Coutinho (1959, p. 61) traz um exemplo metodológico do estudo da "flexão de gênero dos nomes": sugere que o professor faça uma lista com os nomes que aparecem no texto, apontando os gêneros dos nomes a que se referem - será fácil para o aluno concluir que os gêneros dos nomes são dados pela sua terminação e pela sua significação -; a partir dos nomes listados será possível depreender que há nomes que possuem duas formas, uma para o feminino e outra para o masculino (biformes e heterônimos), mas também existem nomes que a mudança faz-se apenas no artigo (comum de dois gêneros), enquanto outros possuem a mesma forma tanto para o feminino quanto para o masculino (sobrecomum), existem também aqueles que são aplicados aos animais machos e fêmeas (epicenos) e ainda os que mudam seu significado quando mudam de gênero (o cabeça, a cabeça); o trabalho deverá ser reproduzido no caderno do aluno e retomado em outras aulas e em outras leituras, ampliando a lista com leituras próprias ou com consultas ao dicionário, sem, no entanto, exagerar com flexões de gênero que nunca vão ser usadas, tendo em vista que a língua visa a satisfazer as necessidades de comunicação. Essas sugestões de Coutinho, apesar de muitos hoje criticarem o uso do texto como pretexto para a análise metalinguística, são inovadoras, pois põem o texto e seu estudo como primazia no ensino da língua vernácula, além de levar os alunos a depreenderem as regras através da análise das formas que a língua adquire no desenrolar do texto. 
Em defesa do ensino da gramática, ouve-se também a voz do professor Jairo Dias de Carvalho $^{12}$ (1960), quando trata do valor e do método de análise sintática. Carvalho afirma que a análise sintática é um "instrumento necessário à aprendizagem real do idioma, uma vez que o elemento básico do discurso é o período" (CARVALHO, 1960, p. 61). O estudo das funções das palavras na oração e o modo como as orações se relacionam no período, segundo ele, é o que permitiria aprender a língua mais com mais eficácia. Para Carvalho, o ensino da análise sintática deve ser feito no ensino médio e deve começar com os termos essenciais - sujeito e predicado -, partindo para os integrantes - complementos verbais, nominais e agente da passiva -, para os acessórios - adjuntos e aposto -, numa ordem gradativa, culminando com o estudo de períodos compostos e com o valor sintático das orações subordinadas substantivas, adjetivas e adverbiais. Essa visão de Carvalho contrapõe-se aos outros artigos já citados aqui Apesar de insistentemente criticada pelos outros autores, a metodologia descrita e ratificada por Carvalho ainda vigora nas aulas de português até os dias de hoje.

\section{CONSIDERAÇÕES FINAIS}

As considerações instigam para a volta à questão que norteia os estudos sobre cultura escolar. As regularidades institucionais, as tradições e a sedimentação práticas que sobrevivem às reformas e inovações são importantes para pensar o porquê de hoje termos um ensino de português com determinada característica. No entanto, reconhecer essas permanências não permite desconsiderar as transformações por que passa a cultura escolar, assim como todos os processos culturais, mas há de se constatar que as transformações pelas quais passou a disciplina de português no Brasil pouco mudaram a concepção predominante na seleção cultural desse ramo de ensino: a de dar primazia à análise gramatical - especialmente morfológica e sintática - e de pautar sua prática na cultura da elite e nos estudos literários.

É possível notar que a revista Escola Secundária abordava questões do dia a dia do professor e que as sugestões fornecidas por ela partiam do que se praticava efetivamente na sala de aula, na tentativa de fornecer diferentes caminhos para a prática docente. Nota-se, também, que grande parte dos autores almejava um ensino integral, educando para a vida, uma interação maior entre as disciplinas e a aquisição da língua culta sem a preocupação com a taxionomia e a classificação -

\footnotetext{
${ }^{12}$ Jairo Dias de Carvalho era poeta, filólogo e professor e pertenceu à associação de linguística e filologia da America Latina, à sociedade brasileira de romanistas, ao centro filológico Clóvis Monteiro, à Ordem dos Advogados do Brasil, à sociedade brasileira de língua e literatura e à Academia Brasileira de Filologia. Disponível em: $<$ http//www.filologia.org.br/rabf/2/195.pdf >. Acesso em: 04/11/2014.
} 
como se pôde notar nos textos, essa é uma tarefa de difícil execução. É importante ressaltar que muitas dessas ideias tinham relação com os ideais escolanovistas presentes entre os intelectuais da CADES e os liberais que ocupavam os segmentos da educação no governo neste período; a revista analisada colaborou, assim, para a disseminação e circulação dessas ideias no campo pedagógico de então. Neste viés, é possível inferir que os artigos foram escolhidos minuciosamente para compor as publicações. Muitos autores da revista, aqui citados - alguns deles seguiram suas carreiras e são, até hoje, lembrados por seus feitos - faziam parte da Academia Brasileira de Filologia, fundada em 1944; ou foram alunos e professores do Colégio D. Pedro II, Colégio modelo do ensino secundário. Essa rede de sociabilidades certamente influenciou a escolha desses autores para compor os números da revista, uma vez que participavam dessas instituições, onde mais se discutiam as prescrições acerca do ensino da língua vernácula e os avanços da linguística.

O "peso asfixiante da rotina" se enraizou na do ensino do vernáculo, mas, como vimos, os artigos aqui citados já ofereciam outros caminhos. A frase de Bechara no artigo publicado em setembro de 1959, n. 10 da Escola Secundária: “Aprende-se a gramática pela língua e não a língua pela gramática" (p. 51), ecoaram na academia e nos círculos de discussão e hoje temos diversos autores que defendem (não) ensinar gramática na escola, como Possenti, Geraldi, Britto e Soares. Ainda há muito que se fazer para que as mentalidades mudem e assim tenhamos um ensino que efetivamente desenvolva a competência linguística do aluno.

É certo que os estudos sobre cultura escolar abarcam tanto o prescrito quanto o praticado. Nosso intuito, neste texto, foi dar subsídios aos pesquisadores que trabalham com a história da disciplina de português acerca do que pensavam os professores na época em que a disciplina sofreu maiores mudanças, pois para desnaturalizar objetos e práticas é preciso conhecê-los a fundo. Reconhecemos ainda a importância e necessidade de maiores investimentos em estudos que visem à caracterização da cultura escolar em torno da disciplina de língua portuguesa para que possamos pensar um futuro mais promissor no compromisso de desenvolver efetivamente a competência linguística de nossos educandos, para que possam, realmente, atuar no mundo e alcançar outros patamares na sociedade por meio do uso da linguagem. 


\section{REFERÊNCIAS}

ARAGÃO, José Aluísio. Princípios gerais que devem nortear o professor de português numa aula de leitura. Revista Escola Secundária, n. 17, p.45, jun. 1961.

BECHARA, Evanildo. A posição da gramática no ensino médio. Revista Escola Secundária. Rio de Janeiro: MEC, n.10. p. 45-52, Set. 1959.

BONAPACE, Adolphina Portela. A aprendizagem da língua vernácula e seus objetivos. Revista Escola Secundária. Rio de Janeiro: MEC, n. 1, p. 29-30, Jun. 1957.

BUENO, Franscisco da Silveira. Gramática normativa da Língua Portuguesa. Revista Escola Secundária. Rio de Janeiro: MEC, n. 3, p. 39, dez. 1957.

BRITTO, Luiz Percival. A sombra do caos: Ensino de línguas x tradição gramatical. Campinas: Mercado das Letras, 1997.

CARVALHO, Jairo Dias. Valor e método da análise sintática. Revista Escola Secundária. Rio de Janeiro: MEC, n.14. p. 61-62, Set. 1960.

CHERVEL, André. História das disciplinas escolares: reflexões sobre um campo de pesquisa. Revista Teoria \& Educação. Porto Alegre: Pannonica, n. 2, 1990.

COUTINHO, Ismael Lima. Sugestões metodológicas para a execução do ensino de português. Revista Escola Secundária. Rio de Janeiro: MEC, n.11. p. 54-64, Dez. 1959.

DELÉO, Antonio F. O ensino de português. Revista Escola Secundária. Rio de Janeiro: MEC, n. 15 p. 52-59, Dez. 1960.

FREIXIEIRO, Fábio Mello. Correlação do português com o latim, a geografia e a história no $1^{\circ}$ colegial. Revista Escola Secundária. Rio de Janeiro: MEC, n. 06. p. 52-55, Set. 1958.

Plano de curso e programa experimentais de português. Revista Escola Secundária. Rio de Janeiro: MEC, n.14. p. 58-61, Set. 1960.

GERALDI, João W. Linguagem e ensino: Exercício de militância e divulgação. Campinas: Mercado das Letras, 2009.

MATOS FILHO, Maurício A. S. et al. Transposição didática em Chevallard: As deformações/transformações sofridas pelo conceito de função em sala de aula.2008. Paraná. Anais eletrônicos. PUC, 2008. Disponível em: http://www.pucpr.br/eventos/educere/educere2008/anais/pdf/431_246.pdf>. Acesso em: 05/11/2015.

PEDRINHA, Alvacyr. Da análise sintática no ensino no português. Revista Escola Secundária. Rio de Janeiro: MEC, n.2. p. 51-53, Set. 1957.

POSSENTI, Sirio. Por que (não) ensinar gramática na escola. Campinas: Mercado das Letras, 2000.

SOARES, Magda. Linguagem e escola: Uma perspectiva social. São Paulo: Ática, 1986.

Português na escola:História de uma disciplina curricular. In: BAGNO, Marcos. [Org]. Linguística da norma. São Paulo: Loyola, 2004. 


\section{RESUMO}

Este artigo tem por objetivo analisar artigos sobre o ensino de gramática de língua no ensino secundário, publicados entre 1957 e 1963, na Escola Secundária, revista trimensal publicada pela Campanha de aperfeiçoamento e difusão do Ensino Secundário (CADES). Por um lado, procuramos compreender o que defendiam os autores desses textos sobre os objetivos do ensino da língua portuguesa; de outra parte, exploramos as opiniões dos artigos acerca dos métodos de ensino e a questão da análise sintática. Para tanto, utilizamos as reflexões de André Chervel sobre as transformações das disciplinas-saber em perspectiva histórica, sendo ensejadas por professores e/ou por manuais escolares e periódicos educacionais.

Palavras-chave: Disciplina-saber; Ensino; Português; Gramática.

The grammar teaching in Secondary School magazine (1957-1963)

\section{ABSTRACT}

This article aims to analyze articles about the teaching of grammar in secondary education, published between 1957 and 1963, in Secondary School, a magazine published every three months by the Campaign of improvement and dissemination of Secondary Education (CADES, in Portuguese). On the one hand, we try to understand what defended the authors of these texts about the objectives of the Portuguese language; on the other hand, we explore the opinions of articles about the teaching methods and the question of parsing. In order to do so, we rely on the reflections of Andrew Chervel about the transformation of disciplinesknowledge in historical perspective, being expected by teachers and / or school books and educational journals.

Keywords: Discipline-knowledge; Teaching; Portuguese; Grammar. 